\title{
Farming travels: a note on cheese-based tourism
}

Francesc Fusté-Forné, University of Girona, Faculty of Tourism, Department of Business

\section{Introduction}

Sustainable farming and agricultural activities advocate for caring and protecting land and nature (Bell, 2010). As traditional economic activities in rural regions, these practices communicate the idiosyncrasies and lifestyles of a culture and its people, in a specific environment (see, for example, Berno \& Fusté-Forné, 2019). From land to table, food is a crucial identity marker (Timothy \& Ron, 2013) which represents the origin of the relationship between agriculture and tourism. As Berno, Laurin and Maltezakis state (2014), "agriculture provides the product; culture provides the authenticity; and tourism provides the infrastructure and services" (p.113). Therefore, the land is the starting point for food tourism. Food tourists are traveling to gastronomic regions in order to visit food producers, farmers markets, festivals and fairs, tasting food products at local restaurants or other food-based tourist activities (Hall \& Sharples, 2003). Authors such as Telfer and Wall (2000) estimate that 'food' constitutes one-third of tourist expenditure, which illustrates the potential of food-based tourism experiences (see McKercher, Okumus \& Okumus, 2008; Novelli, 2005). Both producers and consumers are paying an increasing attention to the role of local foods as an avenue to uncover, communicate and promote a sense of place that express a unique destination identity (see for example Everett \& Aitchison, 2008; Kim \& Iwashita, 2016; Tellström, Gustafsson \& Mossberg, 2006). Cheese reveals a rural terroir and it particularly offers a 'taste of a place' (Trubek, 2008).

Relationships between cheesemaking and tourism industry refer to the process of awarding tourism value to 'cheese'. These connections include pasture lands; cheesemaking processes; and cheese consumption. In this sense, cheese tourism is defined as the journey to regions with a large tradition of milk production and cheese making. This special interest tourism is commonly practiced in rural, natural and mountainous areas. According to Fusté-Forné (2015), "cheese tourism comes from the concern with the process of developing a product closely linked to a territory, and drift towards a typology that includes not only the tourist visit to the craft workshop, but also a set of synergies from complementary food consumption and leisure" 
(p. 91). While some research started to analyse the development of cheese tourism in Northern Europe, particularly in Scandinavia (see Soltani, 2019), this research note approaches its potential for the case of Finland. Outcomes of this study are expected to lead to further studies where the role of cheese tourism in rural development in Finland is analysed, specially from the farmers' perspective.

\section{An approach to the relationships between cheese and tourism in Finland}

Previous research has acknowledged the importance of food tourism in Finland (Tikkanen, 2007), and its role as a tool for rural development (Tyrväinen, Silvennoinen, Nousiainen, \& Tahvanainen, 2001). Earlier publications in this journal reviewed the tourism attractiveness of local food (see, for example, Lüthje \& Saari, 2018), and this research adds a Finnish perspective to the conversation. In this context, Finnish farmers show a growing interest towards organic production (Ahlqvist, 2019) which, in turn, can secure the provision of sustainable food services (Tikkanen \& Jaakkola, 2019). Food is considered an essential ingredient of Finnish tourism strategy (UNWTO, 2017). Adamsson and Havas (2017) affirm that "according to a study by Bloom Consulting commissioned by Visit Finland, the specific search of local gastronomy is the second most popular digital search regarding Finland. The first place is held by nature-related matters. Usually, travellers spend approximately $25 \%$ of their travel budget on food and food-related activities. A traveller whose primary motivation is to explore the local cuisine may spend up to $50 \%$ of his or her travel budget on food. Therefore, it is worth investing in food tourism, it generates also income" (p. 14). Cheese factories and farms are identified as authentic food tourism attractions.

Dairy products largely contribute to Finnish menus. In this sense, "milk production is still the most important source of livelihood in rural areas" (Finnwards, 2020) and the consumption of cheese in Finland has increased from $6.6 \mathrm{~kg}$ per person in 1980 to $25.8 \mathrm{~kg}$ in 2017 (Statistics, 2020). Cooking with cheese becomes more and more popular among Finnish people: "while previously cheese was seen mainly as a topping for bread, it is now increasingly being eaten as a snack and used as a cooking ingredient" (Euromonitor International, 2019). Farmers in Finland make popular cheeses such as Leipäjuusto, Raejuusto, Oltermanni, Aura, Lappi and Turunmaa (AtlasMedia Ltd, 2020). They are examples of cottage, soft and hard cheeses, which are not only made from cow's milk but also from goat's and reindeer's milk - while this latter has been traditionally used to make cheese in Lapland, nowadays its application is mostly limited to cream cheeses.

According to the Food and Agriculture Organization of the United Nations (FAO), "family farming has brought many opportunities and benefits to Finland's society. The base of Finnish farming lies on small and mid-sized farms that are often family owned. Finland has a unique geographical profile with arctic climate conditions, vast forests and numerous lakes that characterize and define the farming models. Due to that, and for historical reasons, Finnish family farming is a source of innovations in combining sources of livelihood - such as tourism, bio economy and forestry - with family farming" (FAO, 2020). In addition, Berno, Laurin and Maltezakis (2014) reported that direct and indirect benefits of linking agriculture and tourism 
are the "increasing economic development; the pride of place, generating attractive, vital and viable rural areas; and a vibrant and locally distinctive tourism product" (p. 105).

A wide range of attraction factors are useful to analyse the relationships between farming and tourism (see Fusté-Forné, 2015). However, only few of them are included in this research note, which explores the potential of cheese tourism in Finland by describing some examples, with the help of literature on food tourism. Practical examples were gathered by the author as part of an exploratory and unstructured non-participant observation case conducted in August 2019, in the cities of Helsinki and Rovaniemi.

As explained above, this study is focused on the case of cheese-oriented tourism. In the context of food tourism experiences, restaurants are regarded as agents for rural development (DiPietro \& Levitt, 2019; Wilson, Fesenmaier, \& Van Es, 2001). Figures 1 and 2 illustrate two dishes (a starter and a dessert) from a restaurant menu where cheese is highlighted as a remarkable flavour of the land. Added to restaurant services, hotels also communicate the sense of place, for example, in breakfast buffets. This is the case of Figure 3, where the taste of Lapland is offered to guests through local products, such as cheeses. The creation of farmer-chef solid relationships is crucial to expand sustainable supply chains that improve the development of rural communities (see for example Crossman, Robles, Petersen, Stanley, \& Wailes, 2009; Thomas-Francois, Joppe, \& von Massow, 2018).

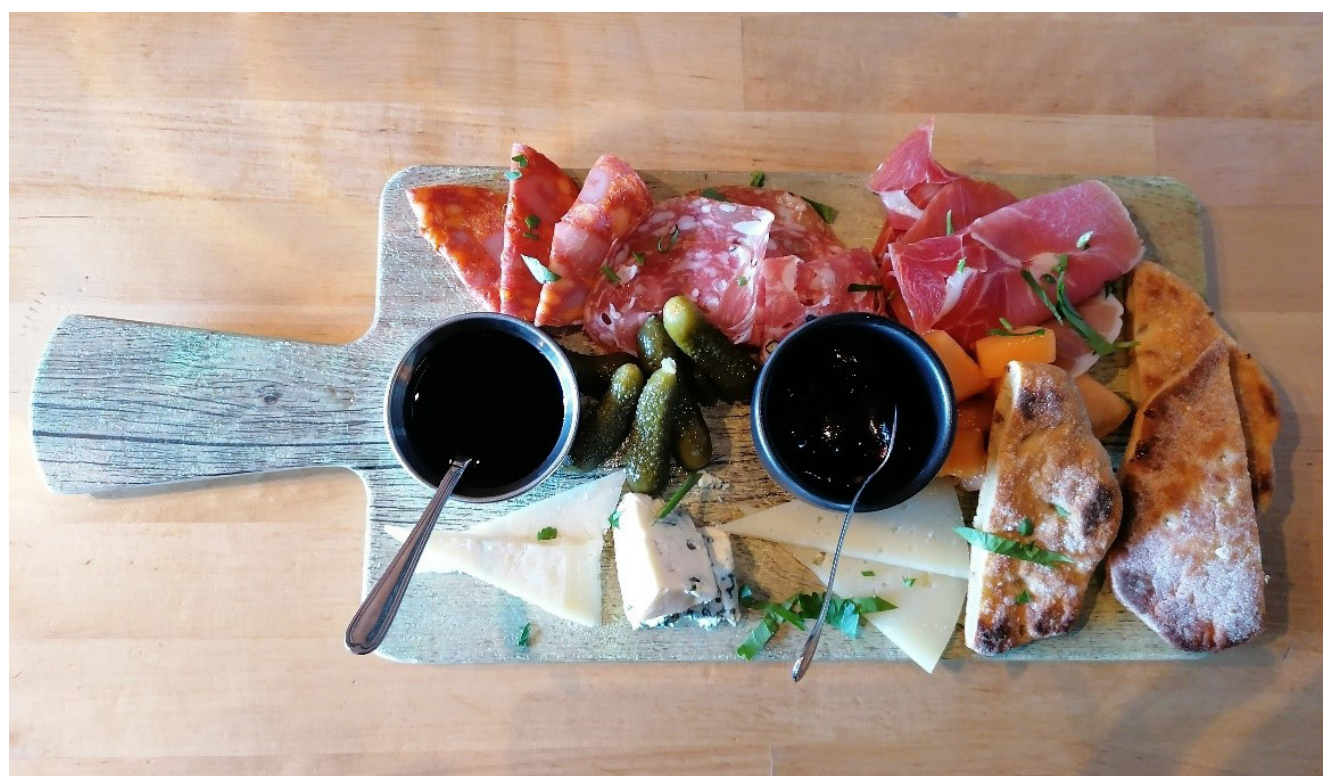

Figure 1. Assortment of charcuterie and cheese, Rovaniemi (Lapland). (Own source.) 


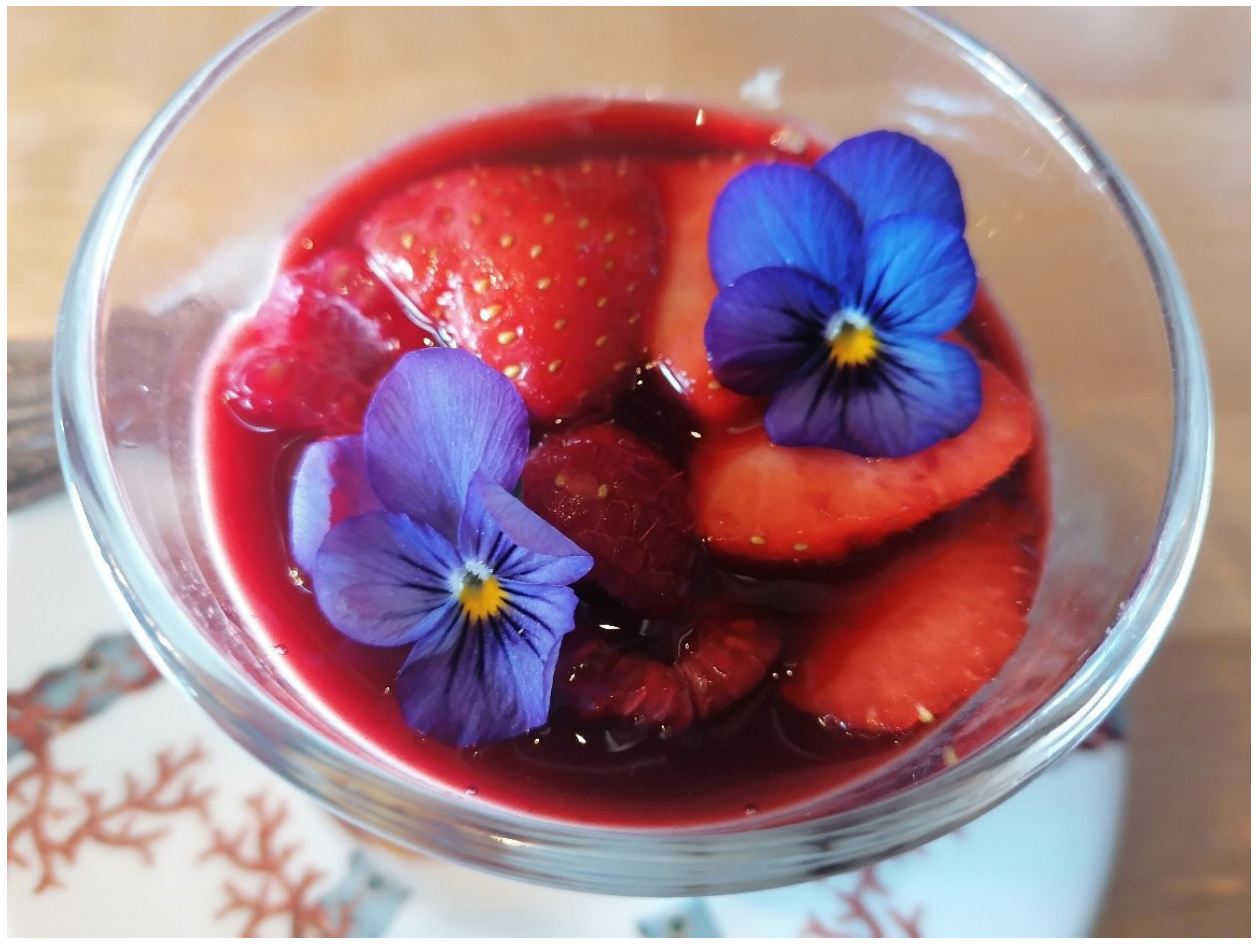

Figure 2. Cheese cake panna cotta with strawberry, Rovaniemi (Lapland). (Own source.)

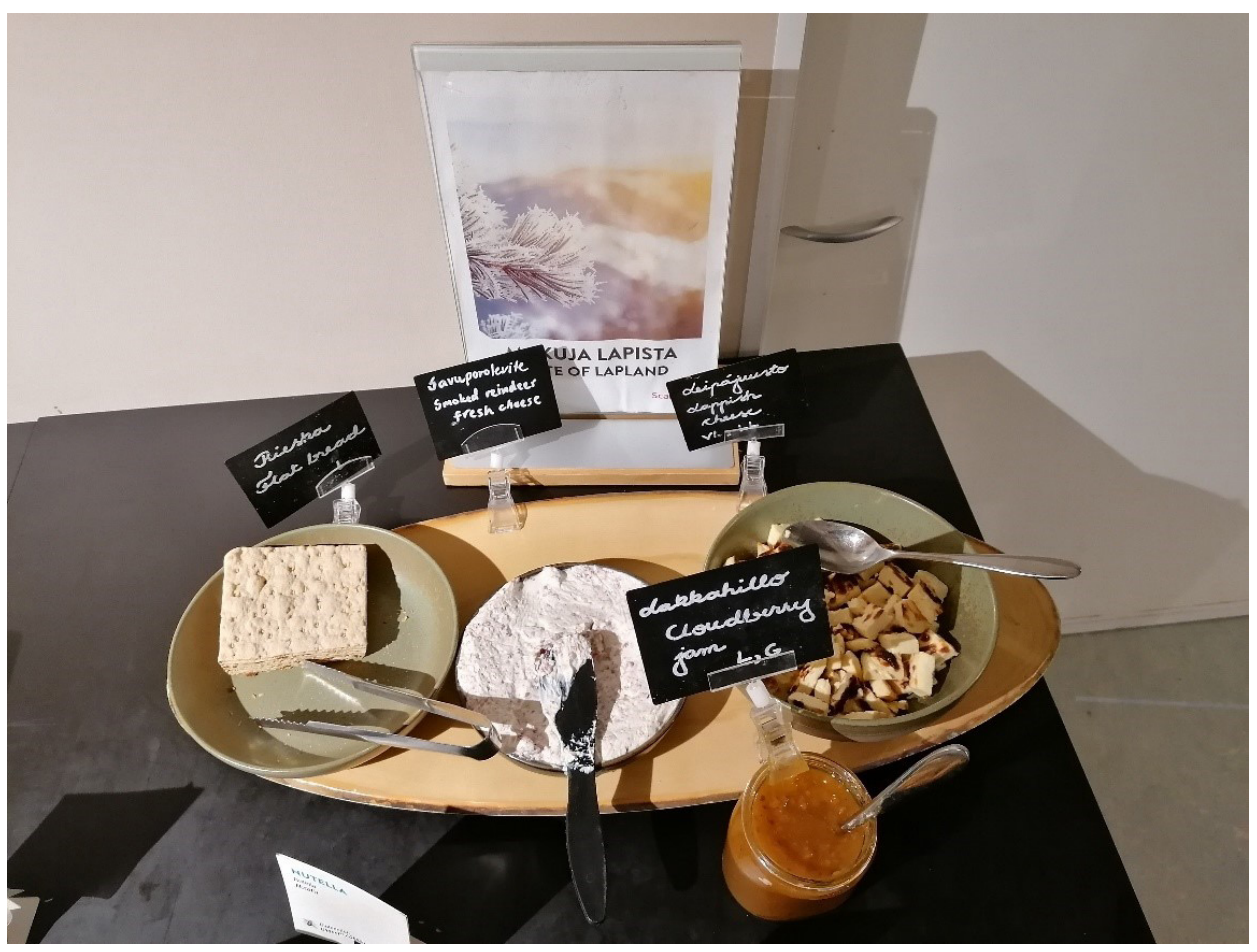

Figure 3. Lapland cheese, bread and jam in a breakfast buffet, Rovaniemi (Lapland). (Own source.) 
Furthermore, there is currently a change towards new collaborative accommodation forms, such as Airbnb (Guttentag, 2015), which implies an increasing use of grocery stores and supermarkets by tourists (Fusté-Forné, 2019). While supermarkets many times appear as examples of global food venues, they also offer local-based produce (Figure 4). The buying of these foods contributes to the engagement of visitors with the cooking process, and accentuates the tourist experience.

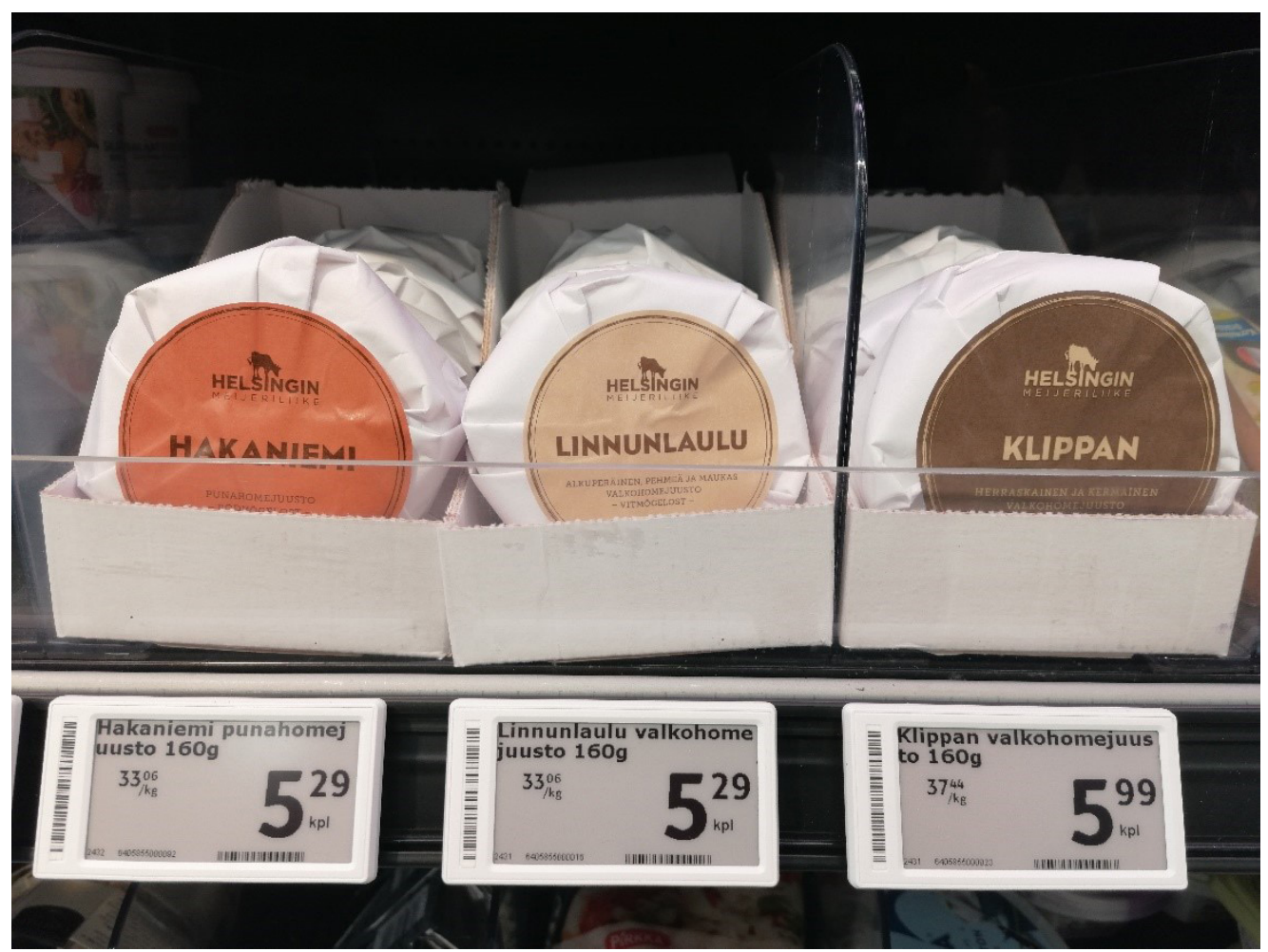

Figure 4. Finnish cheese in a supermarket, Suomenlinna (Helsinki). (Own source.)

\section{Concluding remarks}

From farming to tourism, this research note has approached the relationships between rurality and tourism through the case of cheese in the context of Finland. When tourism services provide local foods, they support regional agricultural activities. Food tourism is an opportunity for farmers not only to develop their businesses (see for example Sidali, Kastenholz, \& Bianchi, 2015), but also to communicate the regional identity and to offer a genuine experience that conveys cultural and natural sense of place (Berno \& Fusté-Forné, 2019; Haven-Tang \& Jones, 2005; Smith, 2015). Figure 5 shows the sustainable process of value creation from farm to table - the case of cheese. Farming activities rely on the landscape, where animals are grazing and feeding. Later, cheese is made of animals' milk. After that, tourism value is awarded to cheese (for example, in restaurants). Specifically, from a Scandinavian perspective, "food tourism may involve a 
delicious restaurant meal, eating a home meal or preparing a Finnish dish under expert guidance. It may include activities related to nature's offerings and picking them as well as eating a meal amid nature and cultural surroundings [...]. Food tourism also links closely with stories, local ties and purity. At its best, a food tourism product gets people involved and doing things that enable the traveller to learn something new, turning the tourism product into an experience" (Adamsson \& Havas, 2017, p. 14).

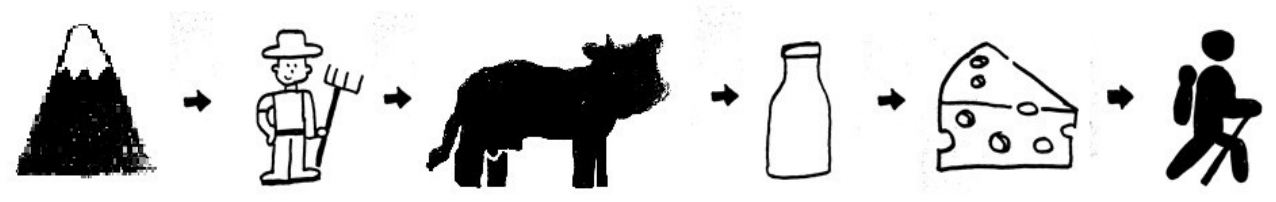

Figure 5. A cheese value travels from land to table. (Own source.)

The development of cheese tourism is aligned with the priorities defined for food tourism planning in the country, which are based on regional food culture ('taste of place'), the nature of food ('pure pleasure') and events and festivals ('cool and creative') (see Adamsson \& Havas, 2017). In this sense, "from pasture to plate, cheeses are identified with a particular landscape; a taste of cheese means a taste of a territory" (Fusté-Forné, 2020, p. 2). Drawing from the description of a series of examples, this research note focused on the potential of cheese-oriented tourism for the case of Finland. Upcoming research is expected to further analyse how farmers can create tourism value for food and how tourists experience place through cheese in the geographical context of the Boreal region of Europe.

\section{References}

Adamsson, K., \& Havas, K. (2017). Hungry for Finland! In K. Havas (Ed.), Changes in the hospitality industry (pp. 14-22). Helsinki: Haaga-Helia University of Applied Sciences.

Ahlqvist, V. (2019). Sustainability in organic farming: An exploration to Finnish farmers' reasons for choosing organic production and their perception of sustainability. Helsinki: Hanken School of Economics.

AtlasMedia Ltd. (2020). Most popular Finnish cheeses. Retrieved from https:/www.tasteatlas.com/ most-popular-cheeses-in-finland

Bell, M. M. (2010). Farming for us all: Practical agriculture and the cultivation of sustainability. The Pennsylvania State University Press.

Berno, T., \& Fusté-Forné, F. (2019). Imaginaries of cheese: Revisiting narratives of local produce in the contemporary world. Annals of Leisure Research. https://doi.org/10.1080/11745398.2019.1603 113

Berno, T., Laurin, U., \& Maltezakis, G. (2014). The special role of agriculture in food tourism. In E. Wolf (Ed.), Have fork will travel: Handbook for food tourism (pp. 105-114). Seattle: World Food Travel Association. 
Crossman, S., Robles, C., Petersen, L., Stanley, D., \& Wailes, E. (2009). Virgin Islands agriculture and tourism linkage: Creating farmer-chef linkages through niche marketing virgin fresh ${ }^{\mathrm{TM}}$ produce. In Proceedings of the 45th Annual Meeting Caribbean Food Crops Society (pp. 138-140). Federation of St. Kitts and Nevis: Caribbean Food Crops Society.

DiPietro, R. B. , \& Levitt, J. (2019). Restaurant authenticity: Factors that influence perception, satisfaction and return intentions at regional American-style restaurants. International Journal of Hospitality and Tourism Administration, 20, 101-127. https://doi.org/10.1080/15256480.2017.1359734

Euromonitor International. (2019). Dairy in Finland. Retrieved from https://www.euromonitor. com/dairy-in-finland/report

Everett, S., \& Aitchison, C. (2008). The role of food tourism in sustaining regional identity: A case study of Cornwall, South West England. Journal of Sustainable Tourism, 16, 150-167. https://doi. org/10.2167/jost696.0

FAO. (2020). Family farming knowledge platform. Retrieved from http://www.fao.org/family-farming/countries/fin/en

Finnwards. (2020). So many different types of milk! Retrieved from https://www.finnwards.com/ living-in-finland/so-many-different-types-of-milk

Fusté-Forné, F. (2015). Cheese tourism in a world heritage site: Vall de Boí (Catalan Pyrenees). European Journal of Tourism Research, 11, 87-101.

Fusté-Forné, F. (2019). Star chefs and the table: From restaurant to home-based culinary experiences. Journal of Culinary Science and Technology. https://doi.org/10.1080/15428052.2018.1563933

Fusté-Forné, F. (2020). Savouring place: Cheese as a food tourism destination landmark. Journal of Place Management and Development, 13, 177-194. https://doi.org/10.1108/JPMD-07-2019-0065

Guttentag, D. (2015). Airbnb: Disruptive innovation and the rise of an informal tourism accommodation sector. Current Issues in Tourism, 18, 1192-1217. https://doi.org/10.1080/13683500.2013.827159

Hall, C. M. \& Sharples, L. (2003). The consumption of experiences or the experience of consumption? An introduction to the tourism of taste. In C. M. Hall, L. Sharples, R. Mitchell, N. Macionis \& B. Cambourne (Eds.), Food tourism around the world: Development, management and markets (pp. 13-36). Oxford: Butterworth Heinemann.

Haven-Tang, C., \& Jones, E. (2005). Using local food and drink to differentiate tourism destinations through a sense of place: A story from Wales-dining at Monmouthshire's great table. Journal ofCulinary Science \&Technology, 4(4), 69-86. https://doi.org/10.1300/J385v04no4_07

Kim, S. \& Iwashita, C. (2016). Cooking identity and food tourism: The case of Japanese udon noodles. Tourism Recreation Research, 41, 89-100. https://doi.org/10.1080/02508281.2016.1111976

Lüthje, M., \& Saari, R. (2018). Paikallisen ruoan matkailullinen vetovoima: Kirjallisuuskatsaus. Finnish Journal of Tourism Research, 14(1), 42-54. Retrieved from https://journal.fi/matkailututkimus/article/view/73028

McKercher, B., Okumus, F., \& Okumus, B. (2008). Food tourism as a viable market segment: It's all how you cook the numbers! Journal of Travel and Tourism Marketing, 25, 137-148. https://doi. org/10.1080/10548400802402404 
Novelli, M. (2005). Niche tourism: Contemporary issues, trends and cases. Abingdon: Routledge.

Sidali, K. L., Kastenholz, E., \& Bianchi, R. (2015). Food tourism, niche markets and products in rural tourism: Combining the intimacy model and the experience economy as a rural development strategy. Journal of Sustainable Tourism, 23, 1179-1197. https://doi.org/10.1080/09669582.2 013.836210

Smith, S. (2015). A sense of place: Place, culture and tourism. Tourism Recreation Research, 40, 220233. https://doi.org/10.1080/02508281.2015.1049814

Soltani, A. (2019). Cultural and touristic aspects of Gamalost, a local cheese from the fjord of Norway. Journal of Gastronomy and Tourism, 3, 271-281. https://doi.org/10.3727/21692971 9X15603602842296

Statistics (2020). Agriculture, forestry and fishery. Retrieved from http://www.tilastokeskus.fi/til/ maa_en.html

Telfer, D. J., \& Wall, G. (2000). Strengthening backward economic linkages: Local food purchasing by three Indonesian hotels. Tourism Geographies, 2, 421-447. https://doi. org/10.1080/146166800750035521

Tellström, R., Gustafsson, I. B., \& Mossberg, L. (2006). Consuming heritage: The use of local food culture in branding. Place Branding, 2, 130-143. https://doi.org/10.1057/palgrave.pb.5990051

Thomas-Francois, K., Joppe, M., \& von Massow, M. (2018). Improving linkages through a service-oriented local farmers-hotel supply chain: An explanatory case in Grenada. Tourism Planning and Development, 15, 398-418. https://doi.org/10.1080/21568316.2017.1338200

Tikkanen, I. (2007). Maslow's hierarchy and food tourism in Finland: Five cases. British Food Journal, 109, 721-734. https://doi.org/10.1108/00070700710780698

Tikkanen, I., \& Jaakkola, L. (2019). Sustainable value chain activities towards sustainable food services: A case study from Finland. Journal of Hospitality and Tourism Insights, 2, 409-424. https://doi.org/10.1108/JHTI-12-2018-0086

Timothy, D. J. , \& Ron, A. S. (2013). Understanding heritage cuisines and tourism: Identity, image, authenticity, and change. Journal of Heritage Tourism, 8, 99-104. https://doi.org/10.1080/174387 3X.2013.767818

Trubek, A. B. (2008). The taste of place: A cultural journey into terroir. London: University of California Press.

Tyrväinen, L., Silvennoinen, H., Nousiainen, I., \& Tahvanainen, L. (2001). Rural tourism in Finland: Tourists' expectation of landscape and environment. Scandinavian Journal of Hospitality and Tourism, 1, 133-149. https://doi.org/10.1080/150222501317244047

UNWTO. (2017). Second global report on gastronomy tourism. Madrid: World Tourism Organization.

Wilson, S., Fesenmaier, D. R., Fesenmaier, J., \& Van Es, J. C. (2001). Factors for success in rural tourism development. Journal of Travel Research, 40, 132-138. https://doi.org/10.1177\% 2F004728750104000203 